\title{
Potentials of Contextual Value-Added Measures in Assisting Schools Become More Effective
}

\author{
Mohamed Yusoff Mohd. Nor ${ }^{1}$ \\ ${ }^{1}$ Faculty of Education, Universiti Kebangsaan Malaysia, Malaysia \\ Correspondence: Mohamed Yusoff Mohd. Nor, Faculty of Education, Universiti Kebangsaan Malaysia, 43600 \\ UKM Bangi, Selangor, Malaysia. Tel: 603-8921-6231. E-mail: yusoff1963@ukm.edu.my
}

Received: July 22, 2014 Accepted: November 5, 2014 Online Published: December 21, 2014

doi:10.5539/ies.v7n13p75 URL: http://dx.doi.org/10.5539/ies.v7n13p75

\begin{abstract}
In a modern society, the schools have become very important entities because they form a social institution, which interests many people and involves the role of various interest groups and stakeholders in the society. The community where a school resides and the parents of children of those who go to that school will be proud if their school if it is categorised as a good school. Conversely, they will blame the school management if it does not perform well in terms of pupils' attainment or if the school's achievement is below the average of the national standards. Parents tend to choose schools, which have a good achievement record for their children. In other words, parents and stakeholders place high expectations on the school. Therefore, it is only natural that school leaders and education authorities as well as every classroom teacher whether in the UK or Malaysia, would want their schools to be more effective when compared to other schools to fulfil the high expectations of everyone in the community. Stakeholders' expectations among others, have been a key driver for the growing interest among education researchers looking for answers to questions such as 'what is an effective school?'; 'school effectiveness for whom?', 'why do we need to have an effective school?', 'how to be an effective school?' and 'what is the accurate, appropriate, reliable and valid instrument to measure school effectiveness?'. This study was based on a literature review carried out at Kings' College London, interviews and observations conducted by the writer during a school placement program in London and the current Malaysian education policies, its practice and school context as the background. It is hoped that the analyses presented will provide better insight and contribute further to our understanding as to the utility of Contextual Value Added (CVA) measures in aiding Malaysian schools to become more effective with special reference to the policy and practiced in the UK schooling system. This study will analyse: How far CVA measures can help schools become more effective and to what extent can Value Added (VA) measures tell us anything significant about the performance of the school concerned?
\end{abstract}

Keywords: Contextual Value Added (CVA), school effectiveness, school management, school performance

\section{Introduction}

Issues relating to school effectiveness, academic achievement and educational equity have received the attention of researchers and policy-makers in developed as well as developing countries (Siow et al., 1999). Basically, School Effectiveness Research (SER) in Malaysia focuses on the characteristic of effective schools and effective leadership which have been found to be key drivers in transforming under performing schools into effective ones (Sharifah, 2000; Beebout, 1972; Isahak, 1977; Hussein, 1979; Leong, 1990; Arif, 1995; Norasimah, 1995; Chin, 1998). In terms of methodology, a number of school effectiveness research in Malaysia used the case study approach where excellent schools were studied in depth to look for factors that contribute to students' achievement.

In the Malaysian context, the Ministry of Education believes that the achievement of every student should not be a function of gender, Social Economic Status (SES), or ethnicity. In other words, an effective school is a school that provides quality education equally for all (Malaysia of Education Ministry, 2006). This assumption is an important evidence to show that our schools can make something happen and defy Coleman's (1966) theory. Equal opportunity to access quality education for all is a crucial policy for Malaysia. This policy can ensure that disadvantaged and deprived schools such as those in remote areas, rural location or low SES population to became effective schools because it is the only learning institution that can economically uplift and modernise 
these deprived communities.

As a developing country, Malaysia needs to ensure the efficiency of educational management through enhancing school effectiveness because of the large investment made in education where the education budget has always been more than those allocated for other sectors enhance. While school effectiveness research has been ongoing for the last two decades, education researchers have yet to agree much on its concept and other underlying theories. Therefore, there is a great need to re-conceptualize school effectiveness so as to avoid over-emphasizing the non-potential factors of effective schools. West and Hopkins (1996) propose that a more comprehensive model for the effective school should focus on four domains:

Student achievement and growth

Student experiences

Teacher and school development

Community involvement

Using West and Hopkins (1996) model, the SER Model was developed. Figure 1 in the following page shows the SER Model which provides a categorization of the important variables found in several school effectiveness studies in Malaysia as well as other developing countries.

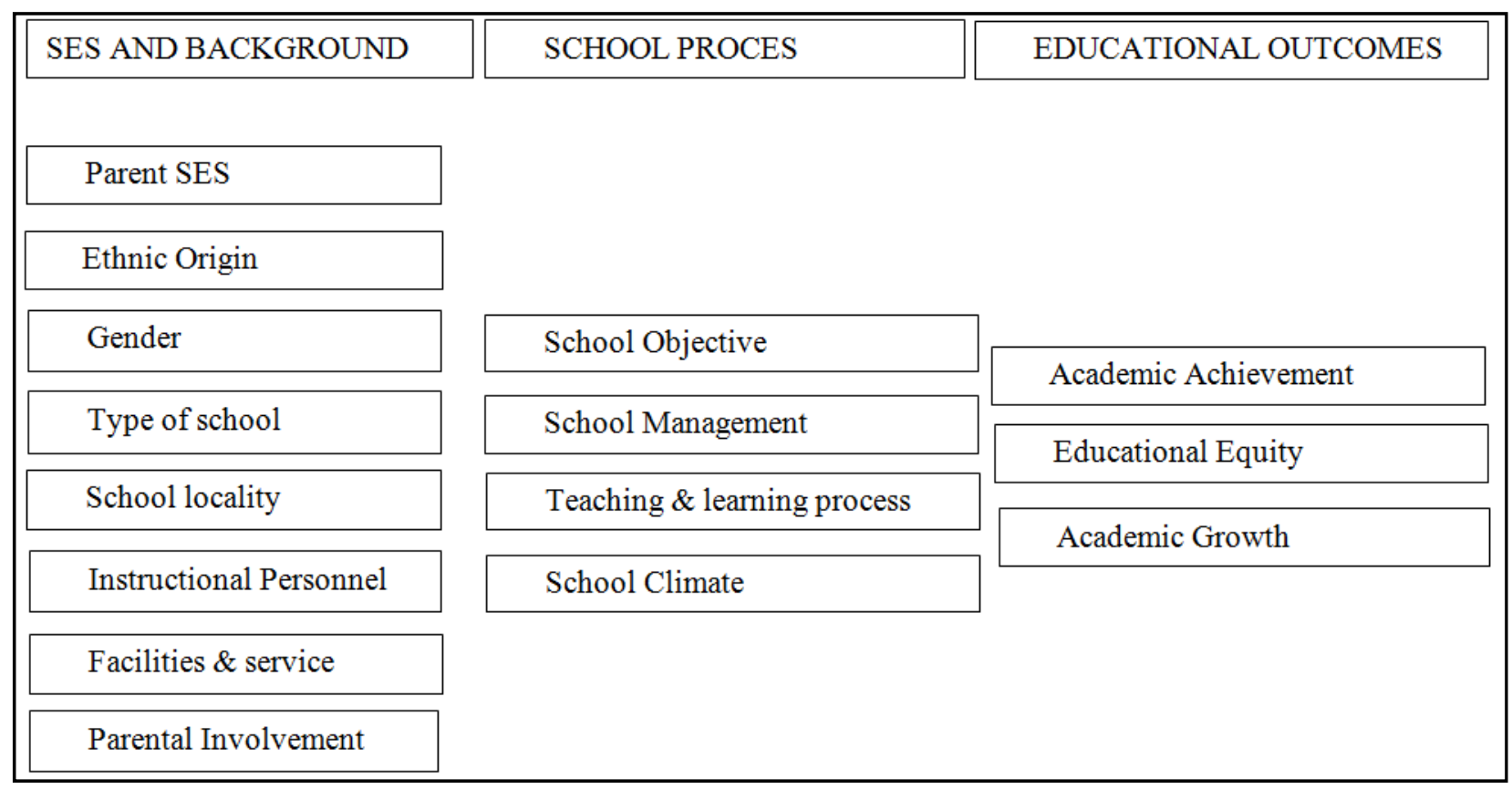

Figure 1. School effectiveness frameworks: categorization of variable

Based on the model showed in Figure 1 above we need to determine which factors are dominant; i.e. whether SES or the school process contributes to pupils' educational outcome. To know objectively the 'what' (context) and the 'how' (process) factors that contribute to a school being effective, not only the schooling system needs to be investigated, we also need to look into the desirable practices by using a practical method of assessment. The measurement tools should be able to show us what is being measured, for whom it is measured, how it is measured and for what we are measuring. International Networking for Educational Transformation (iNet) (2008) in UK showed that those successful schools depend on to what extent the school management uses data effectively as a powerful basis for ongoing review and change. Her Majesty's Chief Inspector, HMCI (2008) of Office for Standard Education, OFSTED for instance also concludes that;

"Data, if used intelligently can be an essential tool as we work together to raise standard in schools, and so improve the lives of the children attending them." (Gilbert \& HMCI, 2008)

Perhaps most of us agree that education is essentially a process with outcomes that are difficult to measure objectively. However, as an education researcher, it is important to determine an objective methodology to 
measure the progress of the activities, and programmes brought about by a certain education policy. A major problem in identifying such a methodology is to determine what factors attributed to the school that is really making a difference in the learning of the students. Is it the homes from which the student came from or the teachers or the teaching? What about the curriculum, the time devoted to the learning, and the resources available to the school? Can we say for sure that maybe perhaps it is a complex combination of these different characteristic about the students, the instruction, the nature of what is taught to the children, or the way in which time is used, and the resources of the school (Madaus, Airasian, \& Kellaghan, 1980). If we can all agree to all of the above as factors that contribute to school effectiveness, we have another question, how can we measure it? The existing assessment practice in Malaysia focusing on summative assessment that is exam oriented. However after several research conducted to measured student achievement as well as student attainment the MoEM introduce new assessment system which the objective to focus on Assessment for Learning.

\section{Value Added and Contextual Value Added Measures Concept}

The concept of VA measures of student achievement or progress has emerged from research into school and teacher effectiveness (Gibbon \& Yymms, 1993; Hill, 1995; Mortimore, Sammons, \& Thomas, 1994; Nuttel, 1992; Scheeren \& Bosker, 1997). According to Sammons (1997), VA score take into consideration "prior achievement of pupil on entry to school' (Thomas, Sammons, \& Mortimore, 1995; Sammons, 1996). The concept of VA is of considerable value in focusing the minds of HTs and teachers on the contribution that the school makes towards the effective learning of individual students (Sammons, 1997). The VA approach emphasizes on evaluating student outcomes directly, or indirectly, via the quality of the teaching and learning process. And certainly, in a broad perspective all the definition of VA have the common aim of assessing the quality and extent of a school's effectiveness in promoting student achievement (Sammons, 1997)

For the purpose of clarity we define the term of value-added more precisely. It is an indication of the extent to which any given school has fostered the progress of all students in a range of subject during a particular time period. (Sammons, 1997)

According to Mortimore (2007) one of the purposes of his research was to explore how VA approaches can be used to study school effectiveness. This technique focuses on student progress over time (for example, from secondary transfer at age 11 to the end of compulsory schooling) and seeks to separate a schools' contribution from that which relate to its intake, by controlling for prior attainment and other background factors.

Bosker and Witziers (1995) offer at least three kinds of VA measures that can be identified, namely:

Unpredicted Achievement (achievement level adjusted for family background factors and student ability);

Learning Gain (student achievement level adjusted for initial achievement level);

Net progress (student achievement level adjusted for family background factor, ability and initial achievement level)

Our respondents in two school in London agree that VA measures provide an indication of educational 'value' that school 'add' to students' achievement over and above that which could be predicted given the backgrounds, abilities and prior achievement of their student intakes. A variety of VA measures can be constructed to indicate difference aspects of educational effectiveness.

According to Ray (2006) there have been two main phases in the development of VA models, both of which are discussed in this writing: (1) simple VA scores based on prior attainment only; (2) more complex 'contextualised' VA or CVA scores based on a range of factors and calculated using multilevel models. In addition to school level scores, VA and pupils' progress information more generally has also been used and presented in graphs and tables.

According to Martimore et al. (1997) that while the role of VA as a mechanism to measure the attainment of pupils in comparison to pupil with similar prior attainment is useful, there are many other factors that are related to the progress that pupils make in a school, such as levels of deprivation or special educational needs. Many studies demonstrated that pupils' background characteristics are related systematically to measures of attainment by age seven years (Mortimore et al., 1988; Tizard et al., 1988; Sammons, West, \& Hind, 1997).

Compared with VA, CVA on the other hand tries to identify and take into account the other pupils' and schools' factors which impact significantly on outcomes. In this respect, CVA provides a more complete picture of school performance and offers a more accurate measure for accountability and improvement purposes. It 'levels the playing field' between schools in different circumstances by taking into account these other factors when measuring the effectiveness of a school or the progress made by individual pupils. Based on 2006 UK SER 
models, they include the following attainment and contextual factors such as: pupil prior attainment, gender, SEN, first language, measures of pupil mobility, age, an 'In care' indicator, ethnicity, FSM, IDACI as well as average and range of prior attainment the school (KS 2-3, KS 2-4 and KS 3-4 only).

Basically CVA provides important and comprehensive information about the effectiveness of a school. This is because, when comparing the performance of schools we must also recognise that pupils will have different starting points. In this case, CVA not only measures progress of prior attainment, but also accounts for the impact of external factors, which in turn have an impact on the progress of individual pupils. In other words, CVA gives a much fairer statistical measure of the effectiveness of a school and provides a solid basis for comparisons since it measures past performance over a given period of time and thus allows comparisons to be made.

\section{Recent SER and the Significant of CVA Measures}

According to iNet (2008), CVA measures include a range within the confidence intervals. The confidence interval is designed to accommodate the uncertainty of CVA score. In a school with a large number of students, the confidence interval is less broad as the calculation is considered more accurate. Conversely, schools, which have a small KS4 cohort, will see that this interval is broader. As a range, we can be confidently say statistically that the values represent a judgment where 'true' school effectiveness will lie.

In term of policy implementation, in UK VA measures have been used in the achievement and attainment tables since 2002. They measure the attainment of pupils in comparison to pupils with similar prior attainment. This is fairer than using raw outcomes since schools can have very different levels of attainment on entry. Currently in the UK, CVA modelling is used: (1) In Performance Tables to provide information to parents and hold schools to account (2) In systems for school improvement, where data is used for self-evaluation and target setting (3) To inform school inspections, which are now tied into the school improvement process (4) To help select schools for particular initiatives (5) To provide information on the effectiveness of particular types of school or policy initiatives.

\section{Data Driven for School Transformation}

The studies showed that data is one of the most important tools in raising student achievement (Reid, 2008). Data of student achievement actually support the concept of assessment for learning and more crucial assessment data to predict and improve student grades and improve of teacher and department estimation to every pupil.

iNet (2008) suggest it is important to have and use CVA data at school department and individual student levels. This can make it clear where students are performing better or worse than estimates based on prior achievement. According to iNet (2008) it is crucial to:

have common understandings about data

analyze pattern and trend for individual groups throughout the school year

have good data at pupil, subject and whole school level to permit comparisons

Data analyses should focus on identifying ISVat the level of individual departments or teachers, based on value-added scores (this generates benchmarks) and on comparing the value-added performance of students in different subjects.

Table 1. Interpreting the ISV Indicator

\begin{tabular}{lll}
\hline CVA Score & ISV Rating & Comments \\
\hline Sig + & L & Progress consistently above average \\
Sig + & H & $\begin{array}{l}\text { Unusual combination. Likely to be the case that most students are making } \\
\text { good progress but some groups (a minority) are making very poor progress } \\
\text { Most students make average progress }\end{array}$ \\
Not sig & L & $\begin{array}{l}\text { Some group of students making good progress but others are making poor } \\
\text { progress } \\
\text { Not sig }\end{array}$ \\
H & Hhilst most groups of students make below average progress there are some \\
where progress is above average & Progress consistently below average \\
\hline
\end{tabular}

Source: iNET (2008) 
Table 2. ISV indicator

\begin{tabular}{l}
\hline $\mathrm{H}$ \\
$\mathrm{L}$ \\
$\mathrm{M}$
\end{tabular}

Source: iNET (2008).

Table 3 below is a summary of the analyses made on 15 specialist schools during the school placement program using CVA. Specifically, the CVA was used to measure the performance of the schools based on their contexts to ensure that the assessments of their performance are fair and accurate.

Table 3. Value-added and educational outcomes: 15 specialist dchools, London

\begin{tabular}{|c|c|c|c|c|c|c|c|c|c|c|c|c|c|c|c|}
\hline School & $\Gamma_{D}^{E}$ & 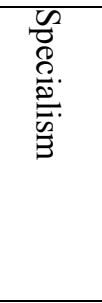 & 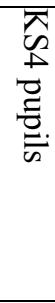 & 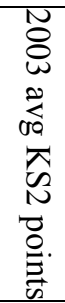 & $\frac{Q}{\stackrel{Q}{Q}}$ & 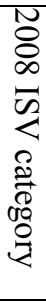 & 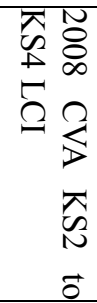 & 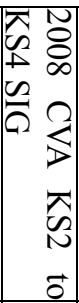 & 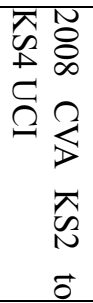 & $\begin{array}{l}\text { D } \\
8 \\
\infty \\
D \\
0 \\
己 \\
2 \\
0 \\
0 \\
ن \\
1 \\
1 \\
0\end{array}$ & 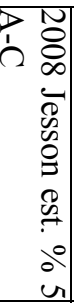 & 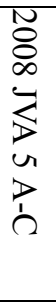 & 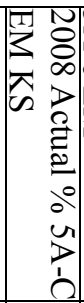 & 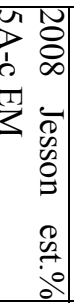 & 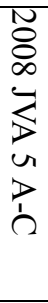 \\
\hline $\begin{array}{l}\text { Anglo } \\
\text { European } \\
\text { School }\end{array}$ & Essex & $\begin{array}{l}\text { Langua } \\
\text { ge }\end{array}$ & 195 & 28.5 & $\operatorname{mix}$ & $\mathrm{H}$ & 978.2 & $\mathrm{Be}$ & 995.9 & 73 & 76 & -3 & 63 & 60 & 3 \\
\hline $\begin{array}{l}\text { Crown Woods } \\
\text { School }\end{array}$ & $\begin{array}{l}\text { Greenwic } \\
\mathrm{h}\end{array}$ & $\begin{array}{l}\text { Human } \\
\text { ities }\end{array}$ & 308 & 25.5 & $\operatorname{mix}$ & $\mathrm{L}$ & 1005.6 & $\mathrm{Ab}$ & 1019.6 & 58 & 53 & 5 & 31 & 35 & -4 \\
\hline $\begin{array}{l}\text { Davennant } \\
\text { Foundation } \\
\text { School }\end{array}$ & Essex & Sports & 168 & 28.9 & $\operatorname{mix}$ & $\mathrm{H}$ & 1010.1 & $\mathrm{Ab}$ & 1028.2 & 88 & 79 & 9 & 85 & 63 & 22 \\
\hline $\begin{array}{l}\text { Greensward } \\
\text { College }\end{array}$ & Essex & $\begin{array}{l}\text { Techno } \\
\text { logy }\end{array}$ & 271 & 27.2 & $\operatorname{mix}$ & $\mathrm{H}$ & 1007.3 & $\mathrm{Ab}$ & 1021.8 & 87 & 66 & 21 & 60 & 48 & 12 \\
\hline $\begin{array}{l}\text { Highdown } \\
\text { School \& Sixth } \\
\text { Form Centre }\end{array}$ & Reading & $\begin{array}{l}\text { Maths } \\
\text { \& Com }\end{array}$ & 183 & 27.1 & $\operatorname{mix}$ & M & 997.8 & $\mathrm{Av}$ & 1016.2 & 54 & 65 & -11 & 51 & 47 & 4 \\
\hline $\begin{array}{l}\text { Newstead } \\
\text { Wood School } \\
\text { for Girls }\end{array}$ & Bradford & $\begin{array}{l}\text { Human } \\
\text { ities }\end{array}$ & 178 & 24.4 & $\operatorname{mix}$ & $\mathrm{L}$ & 989.2 & Av & 1007.3 & 47 & 44 & 3 & 24 & 29 & -5 \\
\hline $\begin{array}{l}\text { Oakland } \\
\text { School }\end{array}$ & $\begin{array}{l}\text { Tower } \\
\text { Hamlets }\end{array}$ & $\begin{array}{l}\text { Scienc } \\
\mathrm{e}\end{array}$ & 112 & 26.8 & $\operatorname{mix}$ & M & 1031.1 & $\mathrm{Ab}$ & 1053.3 & 75 & 62 & 13 & 51 & 48 & 3 \\
\hline $\begin{array}{l}\text { Oakmead } \\
\text { School-Techno } \\
\text { logy College }\end{array}$ & $\begin{array}{l}\text { Bournem } \\
\text { ount }\end{array}$ & $\begin{array}{l}\text { Techno } \\
\text { logy }\end{array}$ & 224 & 25.3 & $\operatorname{mix}$ & $\mathrm{L}$ & 993.9 & Av & 1010.1 & 53 & 51 & 2 & 28 & 34 & -6 \\
\hline $\begin{array}{l}\text { Queensbury } \\
\text { Upper School }\end{array}$ & $\begin{array}{l}\text { Bedfords } \\
\text { hire }\end{array}$ & $\begin{array}{l}\text { Techno } \\
\text { logy }\end{array}$ & 293 & 27.8 & $\operatorname{mix}$ & M & 977.1 & $\mathrm{Be}$ & 991.1 & 63 & 70 & -7 & 54 & 51 & 3 \\
\hline $\begin{array}{l}\text { Riddlesdown } \\
\text { High School }\end{array}$ & Croydon & $\begin{array}{l}\text { Scienc } \\
\mathrm{e}\end{array}$ & 289 & 28.2 & $\operatorname{mix}$ & $\mathrm{H}$ & 980.9 & $\mathrm{Be}$ & 995.1 & 68 & 73 & -5 & 59 & 56 & 3 \\
\hline $\begin{array}{l}\text { Sheffield High } \\
\text { School }\end{array}$ & Essex & $\begin{array}{l}\text { Bus \& } \\
\text { Enterpr } \\
\text { ise }\end{array}$ & 245 & 28.8 & $\operatorname{mix}$ & M & 965.9 & $\mathrm{Be}$ & 981.1 & 65 & 78 & $\begin{array}{l}-1 \\
3\end{array}$ & 58 & 63 & -5 \\
\hline
\end{tabular}




\begin{tabular}{|c|c|c|c|c|c|c|c|c|c|c|c|c|c|c|c|}
\hline $\begin{array}{l}\text { The } \\
\text { Archbishop } \\
\text { Lanfranc } \\
\text { School } \\
\text { (Foundation) }\end{array}$ & Croydon & Sports & 197 & 25.7 & $\operatorname{mix}$ & M & 994.2 & Av & 1011.7 & 47 & 54 & -7 & 32 & 36 & -4 \\
\hline $\begin{array}{l}\text { The Cardinal } \\
\text { Vaughan } \\
\text { Memorial } \\
\text { School }\end{array}$ & $\begin{array}{l}\text { Kensingt } \\
\text { on \& } \\
\text { Chelsea }\end{array}$ & $\begin{array}{l}\text { Maths } \\
\& \\
\text { Compu } \\
\text { ting }\end{array}$ & 114 & 30.5 & Boys & $\mathrm{H}$ & 1015.9 & $\mathrm{Ab}$ & 1037.7 & 90 & 89 & 1 & 90 & 75 & 15 \\
\hline $\begin{array}{l}\text { The Compton } \\
\text { School }\end{array}$ & Barnet & $\begin{array}{l}\text { Techno } \\
\text { logy }\end{array}$ & 153 & 26.9 & $\operatorname{mix}$ & M & 1015.3 & $\mathrm{Ab}$ & 1034.4 & 70 & 63 & 7 & 54 & 45 & 9 \\
\hline Trinity School & $\begin{array}{l}\text { West } \\
\text { Berkshire }\end{array}$ & Arts & 188 & 25.3 & $\operatorname{mix}$ & $\mathrm{L}$ & 979.9 & $\mathrm{Be}$ & 997.3 & 43 & 51 & -8 & 27 & 33 & -6 \\
\hline
\end{tabular}

Source: iNET (2008).

Table 3 above provides an overview of the performance of fifteen schools operating as specialist schools in the summer of 2008. Table 4 below summarises the indicators associated with performance of the fifteen schools in Table 3.

Table 4. CVA

\begin{tabular}{lll}
\hline $\begin{array}{l}\text { Judgement indicator } \\
\text { from DCSF }\end{array}$ & Confidence intervals & $\begin{array}{l}\text { Expressed in the } \\
\text { directory as: }\end{array}$ \\
\hline Below expected & Upper confidence interval (UCI) is less than 1000 & $\mathrm{Be}$ \\
As expected & $\begin{array}{l}\text { Upper confidence interval (UCI) is greater than } 1000 \text { and the } \\
\text { lower confidence interval (LCI) is less than } 1000\end{array}$ & $\mathrm{Av}$ \\
Above expected & Lower confidence interval (LCI) is greater than 1000 & $\mathrm{Ab}$ \\
\hline
\end{tabular}

Source: iNET (2008).

Basically the table above is able to show us some interesting information on the utility of CVA as an indicator school performance. The data also provided the 'drivers' for the schools' transformation. As Professor Alma Harris said,

"Data and self-evaluation are at the heart of sustaining transformation; the use of data provides a powerful basis for ongoing review and change".

The information shown in table 3 above will become meaningless if it is only used for the purpose of grading schools. Conversely it can become more valuable when used as an input during drawing up the schools' development plan especially in measuring whether the schools have performed "below the expected", "as expected" or well as "above expected".

To get a clearer picture of the CVA, we conducted simple survey as an input in our analyses on the role of CVA. The samples were made up a large number of senior teachers from two schools in Essex County, London during the school placement program. The survey tries to answer the question: how far does CVA helps school become more effective. The results are shown in Table 5 below. 
Table 5. How far does CVA measures help schools to become more effective: senior teachers' perspective

\begin{tabular}{|c|c|c|}
\hline CVA measures help us: & $\begin{array}{l}\text { Agree \% } \\
\text { N } 30\end{array}$ & $\begin{array}{l}\text { Disagree } \\
\% \text { N } 30\end{array}$ \\
\hline to measure our pupils' performance & 75 & 25 \\
\hline to monitor pupils' progress & 60 & 40 \\
\hline to identify our teachers' performance & 55 & 45 \\
\hline to know the ranking of our school at national level & 90 & 10 \\
\hline to plan programmes for pupils not achieving expected target & 85 & 15 \\
\hline to share information about pupils' performance among the teachers & 90 & 10 \\
\hline to know the sense of urgency among teachers & 60 & 40 \\
\hline to focus on students' learning & 75 & 25 \\
\hline to increase collaboration among teachers & 60 & 40 \\
\hline to identify pupils' specific needs in education & 90 & 40 \\
\hline to do strategic plan for our school & 75 & 25 \\
\hline to achieve our school's goals & 55 & 45 \\
\hline CVA measures provide us: & Agree \% & Disagree \% \\
\hline good method for Assessment of Achievement Programme (AAP) & 70 & 30 \\
\hline An idea of the factors that influence pupils' progress & 45 & 55 \\
\hline The correlated factors of students' achievement & 55 & 45 \\
\hline reliable information about our pupils' progress & 60 & 40 \\
\hline valuable data to enhance school's performance & 75 & 25 \\
\hline information on how help disadvantage pupils & 85 & 15 \\
\hline Information on how to sustain continuous growth among the excellent pupils & 70 & 30 \\
\hline CVA measures are beneficial to: & Agree \% & Disagree \% \\
\hline our school's operation & 60 & 40 \\
\hline fulfill school governance expectations & 55 & 45 \\
\hline ensure our schooling system is effective & 85 & 15 \\
\hline \multicolumn{3}{|l|}{ CVA is good measurement for: } \\
\hline Comprehensive schools only & / & \\
\hline all types of school & l & \\
\hline under performing schools & / & \\
\hline Excellent schools & / & \\
\hline
\end{tabular}

\section{The Significant of CVA Measures for Malaysia's Schooling System}

In our view the CVA measures are comprehensive, accurate, appropriate, reliable and fair to measure schools' performance, pupils' attainment as well as teachers' performance. However the integrity of CVA measures strongly depends on the integrity of data. This means that data collection must be purposeful, time related, complete (not missing), and clean from any ambiguities and prejudice.

Based on our understanding about the CVA concept, we can conclude that CVA measures help us to know more about the degree of achievement of our students at every level of the schooling system, the national, state or district levels. Not only that, it takes into account students' demographic differences.

In Malaysia, we strongly believe that CVA can help our schools became more effective. For instance, data at the national level (using national level assessment) will provide us an overall view of the schooling system. Further analyses at the state level can help us identify which states have achieved the top rank and conversely those 
states which have not achieved the national target. This information can then be used to identify the issues and problems faced by that particular state.

Similarly, the state level information can be cascaded down the district and schools' levels. At the last and final level, we can identify the performance of every student in a particular school. Thus, it can be seen that CVA can be an important source of reliable and valid information for education authorities at every level for any decision-making and planning purposes. In other words, by utilizing the information given by CVA measures, we can ensure that the practice of data-driven decision making is fully embraced.

In addition to CVA as an important resource in decision-making, the school level CVA can also be an indicator of the school's effectiveness. If all schools involved use the same examination and assessment, this will allow the government to compare the performance of each school against others. However this may not be accurate in most conditions unless we take into consideration the contextual factors which are out of our control. Therefore, CVA measures, which take into account contextual factors, can be appropriately used as school effectiveness indicators with a measure of reservation which can be treated as trivial in most cases. For example, one of the respondents said,

"The CVA data cannot take into account the immediate problem facing by the exam candidate before he or she sit the test. For instance involve in activities, parent problem, social and emotional problem and etc". (Team Leader, Essex County)

However, the respondent strongly agrees that CVA can be useful tool or instrument to identify student's attainment as well as school's performance. CVA according to many respondents is a very reliable measure if the information is specifically used in drawing up the school development plans and strategies to enhance school management. Several of them argued that the CVA is not so beneficial for schools which receive pupils from the good SES since it is difficult to realize the extent to which CVA measures actually help schools to become more effective.

Another perspective from respondents is that ranking schools based on assessment results are meaningless unless the CVA is used during the beginning or the middle of school term. In this way, we can ensure that more intervention is carried out to help states, districts, schools or students which have not reached the designated standards. Another view states that CVA's usefulness is limited because it is more or less historical data and therefore cannot be used as information to plan for the future progress for that particular cohort. Specifically this respondent said,

"In the current situation CVA is a historical data, we not used the CVA data as an input for future planning" (Team Leaders Autonomous School)

\section{How CVA Measures Can Help Schools to Become More Effective?}

According to Hopkins (1996) student performance on assessments can be measured in two very different ways, both of which are important. The first, is achievement. It describes the absolute levels attained by students in their end-of-year tests. Second one is growth, in contrast, describes the progress in test scores made over the school year.

In the past, students and schools have been ranked solely according to achievement. The problem with this method is that achievement is highly linked to the SES of a student's family. For example, according to Educational Testing Service, SAT scores rise with every $\$ 10,000$ of family income. This should not be surprising since all the variables that contribute to high-test scores correlate strongly with family income: good jobs, years of schooling, positive attitudes about education, and the capacity to expose one's children to books and travel, and the development of considerable social and intellectual capital that wealthy students bring with them when they enter school.

In contrast, VA assessment measures growth and answers the question: how much value did the school staff add to the students who live in its community? How, in effect, did they do with the hand society dealt them? If schools are to be judged fairly, it is important to understand this significant difference.

Goldstein $(1987,1995)$ has emphasized the importance of using multilevel techniques and detailed student level data about individual student in calculation a VA measures. The school can use the model below to know the effectiveness school improvement based on student attainment. Basically the school can categorise 4 groups of pupils as shown below. 


\begin{tabular}{|l|l|l|}
\hline \multirow{4}{*}{ Achievement } & $\begin{array}{l}\text { Group 2 } \\
\text { High Achievement } \\
\text { Low Growth }\end{array}$ & $\begin{array}{l}\text { Group 4 } \\
\text { High Achievement } \\
\text { High Growth }\end{array}$ \\
\cline { 2 - 3 } & $\begin{array}{l}\text { Group 1 } \\
\text { Low Achievement } \\
\text { Low Growth }\end{array}$ & $\begin{array}{l}\text { Group 3 } \\
\text { High Growth } \\
\text { Low Achievement }\end{array}$ \\
\hline
\end{tabular}

Growth

Figure 2. Matrix (Source: Hearberg, 2004)

Based on the literature in developing countries,(Teddlie, 2000) group 1, and 3 normally came from deprived and disadvantage pupils, therefore it is crucial to explain that CVA supposes help teachers to identify the strategies on how to help all groups of students based on the CVA added data such as;

Special programmes for group 1 which has low achievement as well as low growth

Find what factors influence group 2 students who are high achievers but with low growth

Identify special programmes to ensure group 3 students can sustain their continuous growth; and

Maintain the good performance for group 4 students.

Based on the varied views, approach, and methodology in SER we would like to propose two models of SER. The first is based on the school as unit analysis and involves various factors. In this model, through regression analysis, we hoped to find a correlation between school context and school programme to students' attainment in the assessment as well as determine which factor dominantly contributes to student attainment.

\begin{tabular}{|c|c|c|c|c|}
\hline $\begin{array}{l}\text { Independent } \\
\text { Variable/School } \\
\text { Context }\end{array}$ & $\begin{array}{l}\text { Intervening Variable/ } \\
\text { School Program }\end{array}$ & $\begin{array}{l}\text { Dependent } \\
\text { Variable }\end{array}$ & $\begin{array}{l}\text { Method of } \\
\text { Analysis }\end{array}$ & Result \\
\hline School Location & Teacher Quality & $\begin{array}{ll}\text { London } & \text { Reading } \\
\text { Test (UK) } & \end{array}$ & Descriptive & Significant \\
\hline Type of School & Contact Hours & GCSE Result (UK) & Correlation & $\begin{array}{l}\text { Not } \\
\text { significant }\end{array}$ \\
\hline $\begin{array}{l}\text { School Size } \\
\text { Ethnic Majority }\end{array}$ & $\begin{array}{l}\text { Teaching Method } \\
\text { Remedial program }\end{array}$ & $\begin{array}{l}\text { SPM Trial Result } \\
\text { (M'sia) }\end{array}$ & Regression & \\
\hline Parent SES & Intervention Program & SPM Result (M'sia) & & \\
\hline First Language & Extra Class & & & \\
\hline $\begin{array}{l}\text { Per cent Free School } \\
\text { Meal }\end{array}$ & $\begin{array}{l}\text { Professional Learning } \\
\text { Community }\end{array}$ & & & \\
\hline Gender & & & & \\
\hline IDACI & & & & \\
\hline
\end{tabular}

Figure 3. The model of SER: School as unit of analysis 
The second model that is proposed uses pupils as a unit of analysis which involves factors closely related with the pupil's background such as behavior, ability, aptitude, attitude etc.

Table 6. The model of SER: Pupil as unit of analysis

\begin{tabular}{llllll}
\hline $\begin{array}{l}\text { Pupil } \\
\text { Characteristics }\end{array}$ & \multirow{2}{*}{ School Characteristics } & $\begin{array}{l}\text { Score } \\
\text { Attainment\% }\end{array}$ & $\begin{array}{l}\text { Score Predicted } \\
\text { Result \% }\end{array}$ & $\begin{array}{l}\text { Actual } \\
\text { Result \% }\end{array}$ & $\begin{array}{l}\text { Value-Added } \\
\text { Point }\end{array}$ \\
\hline SEN & & 50 & 55 & 70 & 15 \\
EAL & 60 & 65 & 75 & 10 \\
Ethnicity & 65 & 70 & 70 & - \\
FSM & Learning Environment & 40 & 45 & 50 & 5 \\
Gender & School Department & 40 & 45 & 55 & 10 \\
Age & Teacher Quality & 50 & 55 & 75 & 20 \\
Mobility & Learning Support & 60 & 65 & 70 & 5 \\
Behaviour & Teaching Style & 70 & 75 & 75 & - \\
Ability & Professional Learning & 40 & 45 & 50 & 5 \\
Attitude & Community & 40 & 45 & 55 & 10 \\
Aptitude & & 50 & 55 & 75 & 20 \\
Learning style & & 60 & 65 & 70 & 5 \\
\hline
\end{tabular}

The first models propose is congruent with some of the respondents' views that every school is different. In contrast, the second model takes into account findings from SER in Malaysia where there exist different styles of learning between boys and girls and teaching practice between male and female teachers. Therefore the second model which has the pupil as unit of analysis can show us the correlation between factors of schools effectiveness and factors associated with pupil's attainment.

Our entire respondent agreed that CVA can provide valuable data to enable the development of effective school development programmes. It works out in this way: CVA gives the teachers in classroom and the education authorities' information about the characteristic for every child group in our schools. Based on the information we can plan programmes which are relevant with the current conditions of the children of the particular school. In terms of policy, this kind of measurement helps us to ensure all of our pupil have access and equal opportunity to quality education.

Based on the input from interview among 20 respondents at Ingatestone and Shenfield which practice VA as an instrument we would conclude that VA measures can be used:

As a tool for school improvement

As a tool for accountability

To inform policy-making

For reporting purposes to parents and community

When asked for more details about the concept and benefits of VA, all of our respondents agreed that value added is not a test or assessment for grading but to measure the effectiveness of teachers to student learning. This point correlates with Hershberg who is convinced that VA is not a test, but a new way of looking at the results that come from tests so that we can determine whether the students in a classroom, school or district are making sufficient academic growth each year (Hershberg, 2005)

\section{To What Extent CVA Can Be Help Schools to Become More Effective?}

VA makes it possible to provide educators with data that allows them to determine the focus of their instruction and their instructional impact. Through this information, teachers, principals, district administrators, and school board leaders can learn whether previously high achievers, middle achievers, or low-achievers are making the most progress, and the extent to which schools and classroom teachers are effective in raising performance (Hershberg, 2005). 
Based on Hershberg point of view we come up with the model of assessment below. This model consists of several independent variables which are: the context using the mean score for take-off reading as indicator while the intervening varible is a treatment program using the mean score after 6 months of treatment as an indicator. For instance, every student is required to sit for a test when he or she registers for a new stage. The result of the tests will show the current student's attainment. After six months, the same student is given the same question after they have been taught in the classroom. The results of the second test can then show to what extent the classroom teaching and learning has been effective. Perhaps we might say, there is no significant difference between prior results with the second test as a null hypothesis. If there is a significant difference between the prior results and the results from the second test, we can reject the null hypothesis and accept that there are significant differences between prior results compared with the second test. In this case, we can say that the teaching and learning in classroom for the six months had increased students' achievement in that particular topic. This is summarized in the following table.

Table 7. The model of SER: how value added work student as unit of analysis

\begin{tabular}{llllll}
\hline Independent & Sit Take off & Intervening Variable & Sit & Method of & Result \\
Variable & $\begin{array}{l}\text { Reading Test } \\
\text { and get the } \\
\text { mean score }\end{array}$ & $\begin{array}{l}\text { Test After 6 Analysis } \\
\text { Month SIP }\end{array}$ & \\
& & And & & \\
& & Get mean score & &
\end{tabular}

Get mean score

\begin{tabular}{llll}
\hline Age & $\begin{array}{l}\text { Special Intervention } \\
\text { Program } \\
\text { intervention in reading } \\
\text { and numeracy }\end{array}$ & $\begin{array}{l}\text { Descriptive } \\
\text { Correlation }\end{array}$ & Significant \\
Gender & Regression & $\begin{array}{l}\text { Not } \\
\text { significant }\end{array}$ \\
Num. sibling $\quad 50$ & $\begin{array}{l}\text { Contact Hours between } \\
\text { pupils and teacher }\end{array}$ & \\
$\begin{array}{l}\text { Num. of year in } \\
\text { Kindergarten }\end{array}$ & Teaching Method & \\
Parent SES & Remedial program & \\
$\begin{array}{l}\text { Parent level of } \\
\text { knowledge }\end{array}$ & Extra Class & \\
& Teacher Quality & \\
\hline
\end{tabular}

We were also able catagorise the students using data from the two schools in the study and the CVA measures. The teachers in the school were convinced that the CVA measures could help identify factors which has the greatest influence on students' achievement.

"Futhemore we could identify the dominant factors that contribute to students achievement and and factors with less influence. Basically the information that we could obtained the teaching styles of teachers and ensured that pupils inclinations are compatible with the methods of teaching practised by the teachers." (Teacher, Essex County)

Basically, we need to understand that, CVA is not a program to neither increase student performance nor help schools to become more effective. CVA measures are actually tools to identify the current conditions that affect school's achievement and student development. More than that, we might say that CVA measures are indicators that can show us how to better plan for change. For instance CVA can show us the level of competencies among the pupils we assess. Through this assessment we can have access to rigorous data which explain that the differences (if it exists) between the current conditions with the desired condition. If we realized that there are gaps between current conditions compare with desired condition, we need to plan to increase pupil development 
with an appropriate and relevant program also based on the research or literature we explored before. For those who are interested and have the ability, this is a great opportunity for them do action research, which purposely explores the problem faced by our pupils who are not achieving the target besides looking also at pupils who show continuous attainment growth.

\section{VA as A Diagnostic Tool}

Almost all of our respondents in the school placement program suggest that VA supposed to be an indicator that makes it possible to provide educators with data that allows them to determine the focus of their instruction (identifying which students have benefited most) and their instructional impact (how effective it has been in providing students with a year's worth of growth from where they began the year). This view support with what is Hersberg theory in our discussion earlier.

According to one of HT through this information, teachers, principals, district administrators, and school board leaders can learn whether previously high achievers, middle achievers, or low-achievers are making the most progress, and the extent to which schools and classroom teachers are effective in raising performance.

According to Gilchrist et al. (2004) VA data are most useful for helping individual schools to pinpoint areas of good practice and aspects of school practice that needs to be improved. Therefore VA should be used as screening instruments to identify individual pupils whose 'predicted' or 'expected' level of attainment are very different from those observed. More importantly this technique enables a school to take into account of factors that may have an impact on pupil outcome such as prior attainment, SES, gender and ethnicity.

According to Hersberg et al. (2004) basically the VA methodology provides powerful diagnostic data to identify and improve the focus and impact of instruction. Based on the data, schools can build learning communities and measure their success through growth, not simply achievement. Hersberg et al. (2004) suggests that Value-added assessment helps school decision-makers determine how effective teachers and school are, how to differentiate truly exceptional changes from predictable ones, and how to use data at the classroom level to make necessary adjustment in pedagogy, curricula, and professional development to bolster learning gains for every children. Through this approach we can use VA as well as CVA as tools for development of educational programmes and not just for the purpose of data collection only.

As a diagnostic tool the VA calculation is concerned not with the score on an achievement test by itself, but with the difference between this actual score and the projected score. Because the key measurement is between these two rather than on the absolute score alone, it does not matter what the mix of students is in a teacher's classroom or in the school or district as a whole. In this sense, VA levels the playing field across schools of very different socioeconomic levels. (Hersberg et al., 2004):

One of our respondent complained that, in current practice CVA data is a historical data. Because of that, we cannot use prior data to be an input for school development plans specifically for a particular cohort of pupils. In other words, CVA in this particular case is simply an instrument to assess learning.

However as an education researcher, I strongly believe that CVA data can be used as inputs for future planning. For instance SPM trial results (equivalent GCSC in UK) can become the baseline data for teachers to do some intervention so that expected targets are achieved. In this situation we might say that we use CVA as a mechanism of assessment for learning because we use the entire result to plan a program that focuses on areas that our pupils are weak in or at risk of not reaching the expected target. 


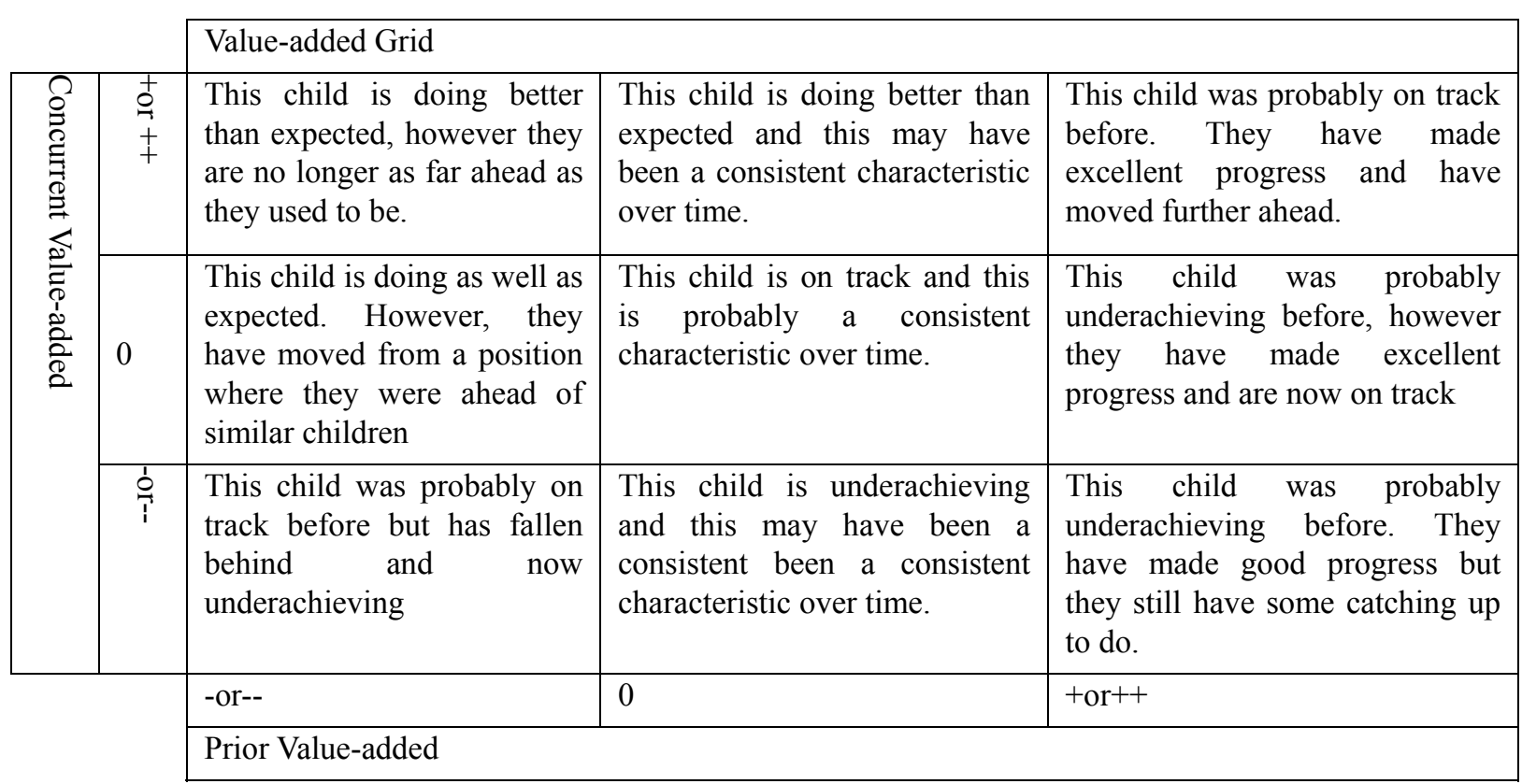

Figure 4. The 'VA Grid' giving descriptions for different combinations of prior and concurrent VA (Source:

Tymms \& Albone, 2002)

One DHT we interviewed said, VA measures is a way of determining pupil attainment by measuring the progress made between key stages and comparing this with the national average. This is seen to be the best guide to a pupil's ultimate performance. According to one AHT who is an expert in assessment for learning under SIP, VA assessment is not just a tool with which to measure progress. However, according him:

VA as a tool can certainly be useful to people working to raise student achievement. So think of it as a stopwatch -it doesn't make people run any faster, but you can use it to time members of the track team, in order to decide how to maximize the strengths of each runner-determining who should run the anchor leg of the relay, how fast a miler should run the first lap, and what training regimens to implement - to achieve the team's overall goals. (Assistant HT, Essex County School)

Likewise, VA assessment provides school leaders with rich diagnostic information, which they can use in many ways such as assigning personnel, allocating resources and identifying mentor teachers and coaches. Furthermore, this tool can help states and school districts to design comprehensive accountability systems that can assess the impact that particular kinds of teaching, curriculum, and professional development have on academic achievement.

\section{What CVA Can and What CVA Cannot}

Based on the survey conducted among senior teachers under school placement program we summarized that CVA is a powerful catalyst for change because it is an assessment to improve AYP measured for:

All students

All major racial/ethnic subgroup

Low-income student

Limited English proficiency student

Student with disabilities

Based on literature (Ray, 2006) and our analysis of CVA measures we conclude that CVA has both advantages as well disadvantages.

The advantages are:

Contextual factors are taken into account in the context.

The hierarchical structure of the data is taken into account through multilevel modelling.

The modelling framework gives external experts more confidence in the approach (although not all agree that 
MLM is appropriate for the purpose of providing value added scores).

VA scores for small scores are less volatile (but also less likely to reveal differences from the mean).

This point of view is supported by Mortimore (1992).

In particular, the development of multi-level analysis and of programs to handle it enables to the data to be treated in an appropriate manner, rather than being reduced to a single level. Thus difference between classes, year groups and schools can be recognized rather than aggregated together arbitrarily (Mortimore, 1992).

\section{Disadvantages}

As an analyst in educational policy, we need to realize that no one measurement tool is perfect, CVA is no exception. In this case we identified several disadvantages of CVA. Ray (2006) in England Report about CVA measures to OECD project concludes that the disadvantage of CVA such as:

A multilevel model may be hard to explain to schools, but so far the consultation process has been positive.

Scores are still not centred on an easily interpreted figure due to the requirements of the Performance Tables which mean that the model has to be calculated on early unlamented data.

It is difficult to get a good fit to the data at the extreme ends of the range. There are still some ceiling effects which are being mitigated with special adjustments

In our opinion, the benefits of CVA measure depend on how we use it. CVA measures perhaps can be meaningless if we use them as a tool for grading the performance of the school. Conversely CVA measure can contribute to identify the level of attainment our student. This is in accordance with some of our respondents' views, who believe that is not fair to judge the school performance based on CVA value if we cannot get the appropriate data or when a school is facing with uncertainties because of external problems such as the cohort of pupil that they have. At other times, schools have to deal with missing data or inappropriate data.

\section{Conclusion and Recommendation}

Take into consideration Coleman et al. (1966) and Jencks et al. (1972) report as a challenge to the school effectiveness researchers, we need to review and examine what, and how schools can give the equity and social justice that are expected to be given to the disadvantage group of students who are solely dependent on schools, because the primary purpose of schools concern is teaching and learning (Sammons, 1999). School effectiveness is also obviously dependent on effective classroom teaching (Cohan, 1983; Scheeren, 1992; Mortimore, 1993; Creemers, 1994). Meanwhile Sammons suggests that there are correlations between the focus on teaching and learning and school and teacher effectiveness.

In this case every school should have planned and structured CPD to increase teachers' competencies and motivation to teaching. Basically every classroom teacher should be competent in curriculum, pedagogy and assessment. These are generic knowledge for teachers and are in constant dynamic change. The question is to what extent HT, DHT, and AHT as well as classroom teachers have the competencies to measure the performance of students and their school objectively. As a instructional leaders we must have clear reasons to explain our successes and the factors that contribute to the successful school?

According to Reid (2008) most successful schools in UK are clear about the reasons of their success. These particular schools have their ability to use and analyze data in order to act to maximize every student's attainment. The study shows the data is one of the most important tools in raising student achievement (Reid, 2008). So we can make a conclusion that the successful school used data effectively.

In line with this, we suggest that CVA be used by all schools in Malaysia to ensure that every pupil have access to quality education In addition, by using information from CVA for policy making, we can ensure that these activities are based on appropriate data and information which is fair and reliable. SER also needs to be given a high priority in improvement programmes as it can contribute to change and innovation in school practices.

Researchers in SER should also use both qualitative and quantitative approaches. In doing so, answers to questions of what is, why and how school effectiveness can be achieved can be consolidated for the benefit of education. In addition, research results should be disseminated widely to initiate policy debates, consideration of alternatives and planned action on sustaining success or mitigate low performance of schools. While developing effective schools can be approached in a number of different ways (Southworth, 1994) approaches should be integrated to provide a comprehensive strategy.

CVA measures and its analyses is the best way to gather school-specific information and proven strategies to create comprehensive strategies such as those suggested by Southworth (1994). 


\section{Reference}

Arif, K. (1995). A Study of Teachers Perception of Principal Effectiveness among Secondary School Teachers in Malaysia (Ph.D dissertation, Michigan University).

Beebout, H. S. (1972). The production surface for academic achievement: an economic study of Malaysia secondary schools (Unpublished Ph.D. thesis). University of Wisconsin.

Bosker, R. J., \& Witziers, B. (1995). School effects: Problems, solutions and a meta-analysis, In A. J. Visscher, \& R. Coe (Eds., 2002), School Improvement Though Performance Feedback. Lisse Swets \& Zeitlinger.

Bowles, S., \& Gintis, H. (1976). Schooling In Capitalist America. London: Kegan Paul.

Gilbert, C., \& HMCI. (2008). Data driven school transformation. iNet: Specialist Schools and Academic Trust, The School Network.

Coleman, J. S., Campbell, E., Hobson, C., McPartland, J., Mood, A., Weinfeld, F., \& York, R. (1966). Equality of Educational Opportunity. Washington: US Government Printing Office.

Creemers. \& Peters, T. (Eds.). (1994). School Effectiveness and Improvement (15, pp. 169-188). School of Education University of Wales College of Cardiff \& RION Institute for Educational Research, Groningen, The Netherlands.

Gibbon, F., \& Tymms, P. (1993); Hill. (1995); Mortimore, Sammons, \& Thomas. (1994); Nuttel. (1992); Scheerens, \& Bosker. (1997). The concept of 'value-added' measures of student achievement or progress emerged from research into school and teacher effectiveness.

Goldstein, H., \& Woodhouse, G. (2000). School effectiveness research and educational policy. Oxford Review of Education.

Hershberg, T. (2005). Value-Added Assessment: Powerful Diagnostics to Improve Instruction and Promote Student Achievement. New York: Women Administrators Conference 2004 Monograpgh

Hopkins, D. (2007). Every School a Great School: Realizing the potential of system leadership. Berkshire: Open University Press

Hopkins, D., West, M., \& Ainscow, M. (1996). Improving the Quality of Education For All. London: David Fulton.

Hussein, A. (1979). Achievement, social environment and background characteristic in lower secondary school: Peninsular Malaysia (Unpublished Ph.D. thesis). Stanford University.

Isahak, H. (1977). Social class and educational achievement in a plural society: Peninsular Malaysia (Unpublished Ph.D. thesis). University of Chicago.

Jencks, C. S. et al. (1972). Inequality: A reassessment on the effect of family and schooling in America. New York: Basic Books.

Knuver, A. W. M., \& Brandsma, H. P. (1993). Cognitive and affective outcomes in school effectiveness research. School effectiveness and school improvement, 4, 189-204. http://dx.doi.org/10.1080/0924345930040302

Hofman, R. H., Hofman, W. H. A., \& Guldemond, H. (1999). Social and cognitive outcomes: A comparison of contexts of learning. School Effectiveness and School Improvement, 10, 352-366. http://dx.doi.org/10.1076/sesi.10.3.352.3499

Chin, L. P. (1998). Ciri-ciri Pengurusan Sekolah Berkesan (Master thesis, UUM, Sintok).

Leong, Y. C. et al. (1990). Factors influencing the academic achievement of students in Malaysian school. A report prepared for the Educational Planning and Research Division, Ministry of Education, Malaysi in conjunction with the Eighth World Bank Loan. Kuala Lumpur: Faculty of Education, University of Malaya

Macbeath, J., \& Mortimore, P. (2001). Improving School Effectiveness. Buckingham: Open University Press.

MacGilchrist, B., Myers, K., \& Reed, J. (2004). The Intelligent School. London. SAGE Publications.

Madaus, F. G., Airasian, W. P., \& Kellaghan, T. (1980). School Effectiveness: A Reassessment of the Evidence. McGraw-Hill Book Company

MoEM. (2006). EDMP, 2006-2010, Putrajaya, EPRD, MOE.

Morley, L., \& Rassol, N. (1999). School Effectiveness: Fracturing the Discourse. London: Falmer Press

Mortimore, P. (2007). The Road to Improvement: Reflections on School Effectiveness. London and New York: 
Taylor \& Francis.

Mortimore, P., \& Whitty, G. (1998). Can school improvement overcome the effects of disadvantage? In P. Mortimore (Ed.), The Road to Improvement: Reflections on School Effectiveness (pp. 299-315). Lisse: Swets and Zeitlinger.

Mortimore, P. (1991). The nature and finding og school effectiveness research in the primary sector. In S. Riddel \& Brown (Eds.), School Effectiveness Research: Its Messages for Improvement. London: HMSO.

Norasimah, A. R. (1995). Ciri-ciri Pengurusan Sekolah-Sekolah Menengah Cemerlang di Kelantan (Master thesis, UUM Sintok).

Sammons, P. (1999). School Effectiveness: Coming of Age in the Twenty-First Century. London: Swets \& Zeitlinger.

Tymms, P., \& Albone, S. (2002). Performance Indicators in primary Schools In A. J. Visscher, \& R. Coa (Eds.), School Improvement Through Performance Feedback. Lisse: Swets \& Zeitlinger.

Ray, A. (2006). School Value-added Measures in England: A paper for the OECD Project on the Development of Value-Added Models in Education System.

Reid, K., Hopkins, D., \& Holly, P. (1987). Toward the Effective School. Oxford. Basil Blackwell.

Reynolds, D., \& Cuttance, P. (1992). School Effectiveness: Research, policy and practice. London: Cassel.

Reynolds, D. (1985). Studying School Effectiveness. London: The Falmer Press.

Rutter, M., Maughan, B., Mortimore, P., \& Ouston, J. (1979). Fifteen Thousand Hours. London: Open Books.

Sammon, P., Thomas, S., \& Mortimore, P. (1997). How can we measure school effectiveness? Chapter 3. In P. Sammons, S. Thomas, \& P. Mortimore (Eds.), Forging Links: Effective Schools and Effective Departments (pp. 23-45). London: Paul Chapman Publishing.

Saunders, L. (2000). 'Understanding schools' use of 'value added' data: The psychology and sociology of numbers'. Research Papers in Education, 15(3), 241-258. http://dx.doi.org/10.1080/02671520050128740

Sharifah. (2000). Keberkesanan Sekolah: Satu Perspektif Sosiologi. Kuala Lumpur Universiti Putra Malaysia, Serdang.

Siow, H. L., Leong, Y. C., Chew, S. B., Suradi, S., Wong, H. H., Quek, A. H., \& Loh, K. W. (1999). Government and Private Secondary Schools: A Comparison of Academic Achievement and Educational Equity: PIER. Kuala Lumpur.

Slee, R., Weiner, G., \& Tomlinson, S. (Eds.). (1998). School Effectiveness for Whom? London: Falmer Press.

Hersberg, T., Simon, V. A., \& Lea-Kruger, B. (2004). In Measuring What Matters: How value-added assessment can be used to drive learning gains. American school Board Journal.

Teddlie, C., \& Reynolds, D. (2000). International Handbook of School Effectiveness Research. London and New York: Falmer.

Teddlie, C., \& Reynolds, D. (2006). The International Handbook of School Effectiveness Research. London: Routledge

Tymms, P., \& Coe, R. (2003). Celebration of the Success of Distributed Research with Schools: The CEM Centre, Durham. British Educational Research Journal, 29(5), 639-667. http://dx.doi.org/10.1080/0141192032000133686

Tymms, P., \& Dean, C. (2004). Value Added in the Primary School League Tables. A Report for the National Association of Head Teachers, May 2004. Durham: CEM Centre, University of Durham.

Weindling, D. (1994). School Development: Lesson from Effective Schools and School Improvement Studies. In S. Geoff (Ed.), Reading in Primary School Development. London: The Falmer Press.

West, M., \& Hopkins, D. (1996). Reconceptualising school effectiveness and school improvement. Paper presented at the School Effectiveness and Improvement Symposium of the Annual Conference of the American Educational Research Association, New York. 


\section{Copyrights}

Copyright for this article is retained by the author(s), with first publication rights granted to the journal.

This is an open-access article distributed under the terms and conditions of the Creative Commons Attribution license (http://creativecommons.org/licenses/by/3.0/). 